\title{
Electronic interaction and digital technologies in corporate governance of a joint stock company in Russia
}

\section{凡 Alexander V. Gabov}

Chief Researcher, Doctor of Juridical Sciences, Corresponding Member of the Russian Academy of Sciences, Institute of State and Law, Russian Academy of Sciences. Address: 10 Znamenka Str., Moscow 119019, Russian Federation. E-mail: gabov@igpran.ru

\section{啡目 Abstract}

The article is devoted to key issues in the development of legal regulation of electronic forms of interaction between participants in corporate relations in Russia. The author consistently examines the development of legislation and the practice of its application since the mid-1990 s. until now. The impact of the emergency legislation created to counter the spread of coronavirus infection in 2020 is separately considered. The author analyzes in detail the materials of the Bank of Russia, various political attitudes. For the first time in special literature, the correlation of the development of electronic forms of interaction in private and public relations is shown. The main current legislative initiatives are considered. The purpose of the study is to formulate the main directions of the development of legal regulation, based on the analysis of the experience of the development of legislation, including regulating public relations. To implement this, the first part of the study (introduction) shows the traditional approach to corporate actions, evaluates its pros and cons; then the second part of the study shows the first attempts in the $2000 \mathrm{~s}$. include elements of electronic interaction in regulations; then (in the third part) a radical change in the legislator's approaches to regulation in 2010 is shown, estimates are given of the state of regulation for the period from late 2019 to early 2020 (before the start of the coronavirus pandemic); in the fourth part of the assessment of current draft laws, as well as the author's proposals in terms of directions of regulation are formulated. Based on the results of the work done, the main conclusion was made about the need to expand the use of electronic forms of interaction for all legal entities, as well as the correlation of private law and public law regulation.

\section{O-1티 Keywords}

corporate governance; joint-stock company; proxy voting; electronic voting (evoting; i-voting; e-proxy voting); remote voting; ballot paper; shareholders' rights; coronavirus infection; restrictions. 
For citation: Gabov A.V. (2021) Electronoc interaction and digital technologies in corporate governance of joint-stock company in Russia. Legal Issues in the Digital Age, no 1, pp. 64-99.

DOI: $10.17323 / 2713-2749.2021 .1 .65 .99$

The modern Russian legislation on joint stock companies (Federal Law of December 26, 1995 No. 208-FZ “On Joint Stock Companies”) in its original version did not provide for the possibility of using electronic communications for interaction between a joint stock company and a shareholder, for counting shareholders' votes; similarly this concerned relations within the collegial bodies of the joint stock company (board of directors, management board and other collegial bodies).

The Law on Joint Stock Companies in a part concerning the meeting of shareholders of a joint stock company provided a traditional form of holding a general meeting in the form of "joint presence" (Articles 50, 55); where personally present shareholders or their representatives could vote by show of hands (i.e., the expression of will was carried out openly) or by filling out ballots with pre-posed questions and dropping such ballots into boxes for their subsequent transfer to the counting commission (i.e., secret ballot). Such a joint meeting required a special room in which the shareholders and their representatives gathered, a system for their registration, and certain rules for holding the meeting.

This traditional way of holding a general meeting of shareholders had its advantages - first of all a personal contact between shareholders and managers of joint-stock companies.

However, it also had its drawbacks. The main one is the significant expenses of the joint-stock company for holding a meeting (rent, payment of postage and other expenses); for shareholders who were not at the place of the meeting, this method of holding meant the cost of arriving at the place of the meeting.

Problems could arise with voting by filling out ballots, which, if incorrectly formatted, could be invalidated.

Another drawback of a meeting in the form of joint presence is the possibility of various kinds of manipulations with the access of a shareholder or his representative to the venue or, on the contrary, creating a situation that entails the need to remove a shareholder (representative) from the meeting, with the subsequent use of this fact to put pressure on the jointstock company [Sychev P.G., 2011]. 
A similar method - referred to as "meeting" (zasedanie) - was envisaged as a form of activity of the board of directors (Article 68 of the Law on Joint Stock Companies) and the collegial executive body of the Joint Stock Company (Article 70 of the Law on Joint Stock Companies).

In addition to joint presence, the Law on Joint Stock Companies provided another form of decision-making by the general meeting of shareholders (as a body of the joint stock company) - by absentee ballot, carried out by sending ballots to the address of the joint stock company. In Anglo-American law, this form is called voting by mail ("distance voting") [Kraakman P. et al., 2017: 58].

A similar form of decision-making - absentee ballot - was envisaged for decision-making by the board of directors of a joint-stock company (Article 68 of the Law on Joint-Stock Companies). At the same time, it should be noted that the procedure for such decision-making could be established by an internal local act of the joint-stock company; accordingly, for this body, absentee voting forms could be more flexible (for example, a paper form might not be used).

\section{The first attempts to include the elements of electronic interactions in legal regulation}

For the first time, the possibility of using electronic tools of communication for the exchange of messages between a shareholder and a jointstock company, as well as between members of other management bodies between themselves and a joint-stock company, was indicated in the Corporate Code of Conduct. ${ }^{1}$

Firstly, the Code of Corporate Conduct recommended (clause 1.1.3) to include in the charter of a joint-stock company a possibility of using an electronic form of notification of a general meeting as an additional way of notifying shareholders about a general meeting. What was meant by the "electronic form of the message" - the document has not disclosed.

Secondly, the document recommended (clause 1.3.5) to provide shareholders with an additional opportunity to get acquainted with information about the meeting of shareholders through electronic means of communication, including the Internet. In addition to referring to such means the Internet, no other details of what is meant by "electronic means of communication" were given.

${ }^{1}$ Order of the Federal Commission for the Securities Market of Russia. April 4, 2002 No. 421. "On Recommendations for the Application of the Corporate Code of Conduct". 
Thirdly, in the part concerning the organizing the activities of the board of directors (supervisory board), the Corporate Code of Conduct recommended (clause 4.5.3) to provide in the internal documents the most acceptable form of notification of the meeting and the procedure for providing information (including by post, telegraph, teletype, telephone, electronic or other communication).

The last two recommendations from the point of view of their implementation (despite the remarks noted above) did not raise questions: in fact, there was no problem in posting information about the meeting of shareholders on the Internet, as well as fixing the provision that notifications and materials for the meeting are sent to a member of the board of directors through various means of communication.

However, the implementation of the first recommendation was associated with difficulties. They were created by the lack of clarity about what the "electronic form of communication" is. In addition, even if such a concept would be disclosed in the internal documents of a joint-stock company, a problem still arose: to implement this method of notification, at least a shareholder's special capabilities (e-mail, fax, etc.) were required; even the posting of relevant information on the Internet at that time (2002) could have had no meaning for a large group of shareholders - elderly individuals who became shareholders following the privatization of the early 1990s. Note also that in the Law on Joint Stock Companies this method of communication - electronic - was not provided. ${ }^{2}$ Electronic exchange between a shareholder and a joint-stock company was not regulated in a special way at all. ${ }^{3}$

Nevertheless, in the same 2002 the Federal Commission on Securities Market (FCSM) (Regulation on additional requirements for the procedure for preparing, convening and holding a general meeting of shareholders) ${ }^{4}$

${ }^{2}$ For example, the word "electronic" (as applied to mail) first appeared in the Law on Joint Stock Companies in 2008, when Art. 15 of the Law, a provision was introduced that in the notification of the reorganization of a joint-stock company, "e-mail addresses" could be additionally indicated for communication with the company. In 2009 (Federal Law No. 352-FZ of December 27, 2009, a similar rule appeared in Article 30 of this Law in terms of requirements for reporting a decision to reduce the authorized capital and Article 35 in terms of requirements for the content of a notice of cost reduction net assets.

${ }^{3}$ Such an exchange (between the depositary and the depositor) was mentioned only by the Regulations on depository activities in Russia, approved by the Federal Commission for the Securities Market. October 16, 1997. No. 36, and only in the form of a blanket norm ("acceptance of documents in electronic form as instructions is allowed if this is provided for by the legislation of the Russian Federation or by agreement of the parties").

${ }^{4}$ Order of the Federal Commission for the Securities Market of Russia. May 31, 2002 No. 17. 
in terms of additional requirements for the procedure for preparing a general meeting of shareholders (clauses 2.1,2.4) determined that in the case of if it is provided for by the charter, proposals on the inclusion of issues in the agenda and proposals on the nomination of candidates to the governing bodies and other bodies of the joint-stock company may be made, and the requirements for an extraordinary general meeting may be submitted by electrical communication, for example, by e-mail using electronic digital signature. ${ }^{5}$

As can be clearly seen, mentioned Regulation of the Federal Commission for the Securities Market of Russia went much further than the Corporate Code of Conduct - it was possible for a joint-stock company to establish (without confirmation in paper form with original signatures and seals) an electronic exchange of separate (three types) legally significant messages.

Between the two documents - the Code of Corporate Conduct and the aforementioned FCSM Regulations of 2002 - in the absence of uniformity in terminology, however, there was an important common point: the issue of using electronic communications to interact with shareholders was left to the discretion of the joint-stock company itself; the documents did not contain detailed regulation.

Thus, the issue of the use of electronic interaction technologies, obviously, was on the periphery of the legislator's attention, and was not in any way significant.

This moment reflected the underdevelopment of electronic document management (here we use this term in a broad sense) at that time, the impossibility of including all shareholders in such interaction (as for shareholders - individuals, such a goal was simply unattainable).

This also reflected, in general, some distrust of document management using various electronic means, which was noted later in various policy documents.

So, in 2010, in the State Program "Information Society (2011-2020)", 6 it was noted that "in economic life, electronic forms of interaction have not

${ }^{5}$ Similar regulation was reproduced in 2012 in the new Regulation on additional requirements for the procedure for preparing, convening and holding a general meeting of shareholders, approved by order of the Federal Financial Markets Service. February 2, 2012 No. 12-6 (clauses 2.1, 2.4, 2.5).

${ }^{6}$ Approved by the order of the Government of the Russian Federation of October 20, 2010 No. 1815-r. 
yet received proper development, including due to a lack of confidence in their safety and security of information, distrust of electronic payments". Six years later, in 2016, the Bank of Russia stated that ${ }^{8}$ "one of the main obstacles to the development of electronic interaction is a psychological or behavioral barrier, largely due to the ignorance of citizens about the possibility of using paperless methods of performing certain financial transactions, as well as distrust of new forms of interaction". ${ }^{9}$

\section{Regulatory changes in the 2010s: from personal participation to electronic telecommuting}

The 2010s are a period when a radical (although not abrupt) change in the situation with electronic exchange of information is taking place, mainly in the relationship between a shareholder and a joint-stock company.

These changes fully corresponded to the goals and objectives that were set by the state at that time in terms of the accelerated development of electronic forms of interaction in all spheres of the economy. For example, the aforementioned State Program of the Russian Federation "Information Society $(2011-2020)$ " as one of its results directly named "interaction of citizens, organizations and public authorities, mainly in electronic form." It should be noted that by this time the practice of using electronic voting in elections both in Russia and abroad had accumulated, which has fully proved its effectiveness [Kersting N., 2007;]; [Pavlushkin A.V., Postnikov A.E., 2009]; [Antonov Ya.V., 2015]; [Tsaplin A.Yu., 2016]; [Matrenina K.Yu., 2017]; [Fedorov V.I., 2017]; [Zakuskin A.A., 2019]; [Khamutovskaya S., 2019]; [Alekseev R.A., Abramov A.V., 2020]; [Kolyushin E.I., 2020]; [Fedorov V.I., 2020].

These changes also took into account the tendencies in the regulation of electronic voting that existed in European practice. For example, in the European Union (in particular, see: Directive 2007/36 / EU of the European Parliament and the Council of 11 July 2007 on the exercise of certain rights

7 Also see: Federal Target Program "Electronic Russia (2002 - 2010)" (one of its latest editions), approved by the Government of the Russian Federation on January 28, 2002 No. 65.

${ }^{8}$ In the Guidelines for the Development of the Financial Market of the Russian Federation for the Period 2016-2018, approved by the Board of Directors of the Bank of Russia on May 26, 2016.

9 See: Main directions of development of the financial market of the Russian Federation for the period 2016-2018. Approved by the Bank of Russia Board of Directors. May 26, 2016. Available at: https://cbr.ru/Content/Document/File/44188/onrfr_2016-18.pdf (accessed: 7.02. 2021) 
of shareholders in listed companies ${ }^{10}$ and Directive (EU) 2017/828 of the European Parliament and the Council of 17 May 2017 amending Directive 2007/36 / EC as regards the encouragement of long-term shareholder engagement ${ }^{11}$ ), as well as in the United States. ${ }^{12}$ Directive 2007/36 / EU, for example, stated that companies should not face legal obstacles in offering their shareholders any means of electronic participation in the general meeting, and voting without personal participation in the general meeting, be it absentee or electronic, should not be subject to restrictions other than those necessary to verify identity and ensure the security of electronic communications. $^{13}$

In 2011 Russia adopted a law that played an important role in the development of electronic forms of interaction between shareholders and joint stock companies (see below) - Federal Law No. 414-FZ of December 7, 2011 "On the Central Securities Depository". This law established (Art. 12) that the Central Securities Depository, its clients (depositors), as well as the persons maintaining the register are obliged to exchange information and documents in electronic form when interacting with each other.

The most significant changes in attitudes towards the electronic exchange of information between a shareholder and a joint stock company at the political and legal level took place in 2013. The action plan ("road map") "Establishing an international financial center and improvement of the investment climate in the Russian Federation", ${ }^{14}$ in the section on corporate governance, ${ }^{15}$ included a special para 44: "Regulation of electronic methods of interaction between shareholders and a joint stock company." According to this paragraph, it was envisaged in 2014 to establish legal norms (to develop a draft federal law and other legal acts ${ }^{16}$ ) "regulating

${ }_{10}$ Available at: https://eur-lex.europa.eu/legal-content/EN/TXT/PDF/?uri=CELEX:32007 L0036\& from=EN (accessed: 1.03 .2020 )

11 Available at: https://eur-lex.europa.eu/legal-content/EN/TXT/PDF/?uri=CELEX: 32017L0828\& from=EN (accessed: 1.03 .2020$)$

12 Available at: https://ssrn.com/abstract=1731362 (accessed: 1.03 .2020 )

13 "Companies should face no legal obstacles in offering to their shareholders any means of electronic participation in the general meeting. Voting without attending the general meeting in person, whether by correspondence or by electronic means, should not be subject to constraints other than those necessary for the verification of identity and the security of electronic communications".

${ }^{14}$ Approved by the order of the Government of the Russian Federation of June 19, 2013 No. 1012-r.

15 "V. Corporate governance and enforcement, including investor protection, insolvency resolution, contract execution, financial market dispute resolution."

${ }^{16}$ That is, initially it was supposed to have two levels of regulation - legal and sub-legal. 
electronic means of interaction between shareholders and the company." Such an impulse was fully consistent with a significant change in public attitudes towards electronic forms of interaction - the availability of the Internet, the prevalence of electronic devices has sharply increased, the composition of shareholders has changed qualitatively. ${ }^{17}$

It should be noted para 44 of the Action Plan "Establishing an international financial center and improving the investment climate in the Russian Federation" was not implemented - a special law on its implementation was never adopted. However, in 2014, the Federal Law of July 21, 2014 was adopted, ${ }^{18}$ which supplemented the Federal Law "On the Securities Market" with a special article 8.8 "Specifics of participation in the general meeting of persons whose rights to securities are accounted for by a nominal holder".

According to this article, the following rules of electronic interaction were established in preparation for a general meeting of shareholders with the participation of an issuer (joint-stock company), a shareholder, a nominee holder, a registrar, a central depository [Chekhovskaya S.A., 2016: 77], as well as a voting procedure (the first Russian version of a mechanism long known in Western countries, designated in literature by the term "e-proxy voting") [Novoselova L., Medvedeva T., 2017] ; [Kraakman R. et al., 2017]. ${ }^{19}$

The main provisions of the mentioned law are as follows:

the owner of the securities, as well as any other person who, in accordance with federal law, exercises the rights to securities, the rights to which are accounted for by the nominal holder, received the right to take part in

${ }_{17}$ During this period, there are also rare works in which attempts are made to assess the possibility of using electronic technologies in the implementation of corporate actions [Druzhinin A., 2012].

${ }_{18}$ Judging by the text of the explanatory note to the draft Federal Law No. 359513-6 "On Amendments to Certain Legislative Acts of the Russian Federation in Connection with the Adoption of the Federal Law" On Guaranteeing the Rights of Insured Persons in the System of General Pension Insurance of the Russian Federation in the Formation and Investment of Pension Savings Funds the corresponding changes were not planned initially. This is understandable - it is clear from the title that the document was originally developed for completely different purposes. According to the Table of amendments to the draft federal law No. 359513-6, recommended by the Committee on the Financial Market for adoption during the consideration of the draft in the second reading, the corresponding changes - the introduction of Art. 8.8 to the Law on the Securities Market - were proposed by the deputy of the State Duma Natalia Burykina.

19 In fact, the first Russian version of voting with the participation of intermediaries, which is known in foreign practice as "proxy voting" or "proxy voting through custodial institutions or other intermediaries”. 
the general meeting of the owners of securities by giving instruction ${ }^{20}$ to the nominal holder to vote in a certain way; such a right could arise only if it was provided by an agreement with a nominee holder;

the issuer of securities, if a personal account of the nominal holder of the central securities depository has been opened in the register of securities holders, - must ensure that securities holders can participate in the general meeting by sending an electronic document signed with an electronic signature;

the registrar is obliged to send the information contained in the voting ballot to the central securities depository and the nominal holder registered in the register of securities holders in the form of an electronic document signed with an electronic signature;

the voting document containing the information required by law ${ }^{21}$ was formed by the nominee holder on the basis of instructions received from the owner of the securities. The nominee holder sent the voting document to the registrar, and if such a nominee holder is a depositor of another nominee holder, to such a nominee holder. The voting document was signed with an electronic signature.

The main problem of the new regulation was the lack of corresponding provisions ensuring the real "functioning" of the e-proxy voting mechanism in the legislation on joint stock companies. ${ }^{22}$

In addition to the Law of July 21, 2014 No. 218-FZ, another document appeared in 2014, which described a recommendation on the use of document automation between a shareholder and a joint stock company - the Corporate Governance Code (Information Letter of Bank of Russia of April 10, 2014 No. 06-52 / 2463), which replaced the 2002 Corporate Code of Conduct.

${ }^{20}$ Literally, the norm looked like this "personally or by giving instructions"; it is difficult to say why it was formulated in this form, since this article is clearly not a suitable place to describe such a fundamental issue as the right to participate in the general meeting of securities holders.

${ }^{21}$ The voting document must contain information on the owners of securities and on other persons who, in accordance with federal law or personal law, exercise the rights to securities, on the number of securities owned by such persons, as well as the results of their voting on each item on the agenda of the general meetings of owners of securities.

${ }^{22}$ It should be noted that in the 2014 report of the Bank of Russia "Barriers to the development of electronic interaction in the financial market" it was stated that "in the field of corporate relations, a significant gap is the lack of a legislative framework for creating an electronic system of interaction between shareholders and a joint-stock company" Available at: https://cbr.ru/finmarkets/files/interaction/1a.pdf (accessed: 1.03.2021) 
In accordance with the 2014 Corporate Governance Code (currently in force), the following recommendations are provided:

the notice of the general meeting and materials thereto are sent to shareholders, whose rights are recorded by depositories (nominee holders) in electronic form;

joint stock companies were recommended to provide an opportunity for shareholders, whose rights are recorded in the register, to receive a notification about the meeting and have access to the meeting materials in electronic form at request of a shareholder;

joint-stock companies were advised, in addition to posting on the Internet a message about the upcoming general meeting of shareholders, to post materials for the meeting in question on their websites;

joint-stock companies were recommended, taking into account the technical capabilities, "to strive to create a convenient procedure for shareholders to send to the company requests to convene a general meeting, proposals for nominating candidates to the company's bodies and making proposals to the agenda of the general meeting"; while and it was recommended "to use modern means of communication and provide the exchange of information in electronic form";

joint-stock companies were recommended to "create systems, taking into account the technical conditions, allowing shareholders to take part in voting using electronic means". In particular, it was recommended "in order to create the most favorable conditions for the participation of shareholders in the general meeting, provide for the possibility of filling out a voting ballot in electronic form, for example, through a personal account on the company's website on the Internet, provided that sufficient security and protection is ensured, as well as accurate identification of persons, taking part in the meeting";

joint-stock companies with a large number of shareholders were advised to use telecommunications to ensure remote access of shareholders to the general meeting (for example, to broadcast the general meeting of shareholders on the website of the joint-stock company on the Internet, use video conferencing);

to implement the principle of accessibility of disclosed information, joint stock companies were recommended to use a variety of channels and methods of disclosing information, primarily electronic, accessible to the majority of interested parties; 
joint-stock companies were recommended "taking into account ... technical capabilities ... to strive to create a convenient procedure for shareholders to send requests for access to information and documents of the company (in particular, to regulate the use of modern means of communication and exchange of information in electronic form)";

joint stock companies were recommended to provide information and documents to shareholders "in a way convenient for shareholders and in a form appropriate for them, including using electronic media and modern means of communication (taking into account the wishes of those who sent the request to provide documents to the form of their provision and the method of their delivery)".

The implementation of these recommendations was complicated by the lack of legislative regulation of electronic interaction. The Bank of Russia, in its Review of Corporate Governance Practices in Russian Public Companies, prepared on the basis of public data disclosed by companies in their 2015 annual reports, noted that "most companies ... are experiencing difficulties ... with the provision of electronic means of remote access to shareholders' meetings ..."23

It was recommended to use electronic forms of interaction when interacting with members of boards of directors (supervisory boards), namely, it was recommended:

"to fix in internal documents the provision that when holding meetings of the board of directors in person, to determine the presence of a quorum and voting results, a written opinion on the agenda of a meeting of a member of the board of directors who is absent from the meeting is taken into account. It is necessary to determine the procedure for obtaining a written opinion from a member of the board of directors, ensuring its prompt direction and receipt (for example, by telephone or electronic communication)";

to provide in the internal documents "a form of notification of a meeting and a procedure for sending information, ensuring its prompt receipt (including via electronic communication), most acceptable for members of the board of directors."

In 2015, the G20 / OECD Principles of Corporate Governance appear. This document:

${ }^{23}$ See: Overview of corporate governance practices in Russian public companies based on disclosed by companies in 2015 annual reports, P. 17. Available at: http://www.cbr.ru/ collection/collection/file/24046/review_17042017.pdf (accessed: 7.02.2021) 
welcomes - as a measure "to remove artificial barriers to participation in general meetings of shareholders" - to encourage the use of "electronic absentee voting, including the submission of electronic materials and reliable systems of confirmation of votes";

notes the need for widespread use of "information technology in the voting process, including secure electronic voting in all public companies." ${ }^{4}$

In 2015 a document was adopted that was not directly aimed at expanding the electronic interaction of participants in corporate governance, but had an impact on their development - the Action Plan for the development of electronic interaction in the financial market. ${ }^{25}$ Among the goals of this document there were such as "consistent reduction of paper workflow in the financial market", as well as "creation of prerequisites for the refuse of paper workflow in the financial market."

The apogee in the development of electronic methods of interaction of a joint-stock company with shareholders in the 2010s was adoption of the Federal Law of June 29, 2015 No. $210-F Z,{ }^{26}$ as a result:

the e-proxy voting mechanism has been changed. In particular, Art. 8.8 of the Law on the Securities Market ceased to be in force. A new article was introduced into the Securities Market Law - Article 8.9. Specifics of the exercise of rights to securities by persons whose rights to securities are accounted for by a nominal holder.

If earlier Art. 8.8 of the Law on the Securities Market was the only rule describing the e-proxy voting mechanism, then Art. 8.9 of the Law on the Securities Market (after the adoption of Law No. 210-FZ dated June 29, 2015) has become only a part (albeit an important one) of this mechanism.

This article provides ${ }^{27}$ that the person exercising the rights to securities (shareholder), if the rights to them are accounted for by the nominee holder, is entitled by giving instructions: ${ }^{28}$

${ }^{24}$ Available at: https://www.oecd-ilibrary.org/docserver/9789264252035-ru.pdf?expires $=1611827492 \& \mathrm{rid}=\mathrm{id} \&$ accname $=$ guest $\&$ checksum $=23 \mathrm{DA} 6 \mathrm{~A} 3733 \mathrm{~B} 03278 \mathrm{~B} 2653 \mathrm{E}-$ 853207C9A5 (accessed: 7.02.2021)

${ }^{25}$ Available at: http://static.government.ru/media/files/woFl5dADTluVf5jIgAmGI0vbegU74awz.pdf (accessed: 7.02.2021).

${ }^{26}$ This bill was not aimed directly at the development of electronic document management.Available at: https://sozd.duma.gov.ru/bill/469229-5 (accessed 7.02.2021)

${ }^{27}$ If it is provided by the contract of the person with such an organization.

${ }^{28}$ According to this article, the procedure for giving instructions is determined by an agreement with these organizations. 
to propose agenda items for the general meeting of securities holders;

to nominate candidates to the governing bodies and other bodies of the joint stock company;

to demand the holding of a general meeting of owners of securities;

to take part in the general meeting of owners of securities and exercise the right to vote;

Organizations, having received instructions, send an e-message containing the expression of the will of the person exercising the rights to securities to the person with whom an agreement has been concluded on opening a personal account (depo account) of a nominee holder.

To exercise the right under Art. 8.9 of the Law on the Securities Market, in accordance with the amendments made to Art. 60 of the Law on Joint Stock Companies, receipt by the registrar of a joint stock company of messages on the will of persons who:

have the right to participate in the general meeting of shareholders;

are not registered in the register of shareholders of the joint stock company; shares;

gave instructions on voting to the persons registering their rights to

is equivalent to voting by ballots.

At the same time, according to the changes in Art. 58 of the Law on Joint Stock Companies, shareholders who have given instructions on voting to persons registering their rights to shares are considered to have taken part in the general meeting of shareholders if notifications of their will are received no later than two days before the date of the general meeting of shareholders or until the deadline for admission ballots when holding a general meeting of shareholders in the form of absentee voting;

the forms and methods of communicating information about the meeting to the persons registered in the register have changed significantly:

the Law on the Securities Market was supplemented with a new article 30.3 , according to which the issuer is obliged to provide information related to the exercise of rights on securities to the central securities depository, if a personal account of the nominal holder of the central depository is opened for him in electronic form in the manner and formats established by the central depository; 
Art. 52 of the Law on Joint Stock Companies was supplemented with an indication that the charter of a joint stock company may provide for other methods of communicating information about the holding of a meeting, except for sending registered letters or handing over against signature. It is now allowed to specify the following methods in the charter:

sending an electronic message to the email address indicated in the register of shareholders of the company and / or;

sending a notice of the general meeting of shareholders to the contact phone number or e-mail address, which are indicated in the register of shareholders of the company and / or;

publication in a print form specified in the charter of the company and / or posting on a website specified in the charter of the company, ${ }^{29}$

provides the possibility of electronic registration for participation in the meeting of shareholders - Art. 58 of the Law on Joint Stock Companies indicates that the following are considered to have taken part in the general meeting of shareholders;

shareholders who have registered to participate in it, including on the website specified in the announcement of the general meeting;

shareholders whose electronic ballot papers are filled out on the specified website no later than two days before the date of the general meeting of shareholders. To fill out the electronic ballot on the indicated website, Art. 54 of the Law on Joint Stock Companies provides that in preparation for such a meeting, the board of directors of a joint stock company must determine the address of the website, where the electronic form of ballots can be filled out;

the procedures for remote interaction during voting have been regulated (from the moment the ballot is sent to the shareholder and until it is received back by the joint stock company), namely:

Article 49 of the Law on Joint Stock Companies has been supplemented with a separate clause 11, according to which, during an in-person meeting of shareholders, communication technologies can be used to ensure the possibility of remote participation of shareholders to discuss agenda

${ }^{29}$ Let's note that some researchers, pointing out the limited use of other electronic technologies, explain this by the fact that "there is no contractual relationship between the registrar and the persons registered in the register, while any use of electronic documents when providing information to shareholders requires the conclusion of a separate agreement for the purpose of giving legitimacy to these electronic documents "[Medvedeva T.M., Azimova L.V., 2020: 66-67]. 
items and make decisions on issues put to a vote without being present at place of the meeting. This rule, in essence, is an attempt to transfer the provisions of the 2014 Corporate Governance Code into federal law. This attempt cannot be recognized as fully successful - this rule does not agree with other provisions of the Law on Joint Stock Companies (even terminologically). It should also be noted that the wording of the above rule clearly excludes the possibility of holding a meeting with remote electronic participation of all shareholders (or their representatives) [Medvedeva T.M., Azimova L.V., 2020: 72];

according to the changes in Art. 60 of the Law on Joint Stock Companies, the charter of a joint stock company may provide for the sending of a voting ballot in the form of an electronic message to the email address specified in the register of shareholders of the company when holding a general meeting of shareholders:

in the form of absentee voting;

in a public joint stock company;

in a non-public joint stock company with the number of shareholders - owners of voting shares of 50 or more;

in another company, the charter of which provides for the mandatory sending or delivery of ballots before the general meeting of shareholders.

To implement the possibility of sending a ballot to the shareholder in electronic form: Art. 54 of the Law on Joint Stock Companies provides that in preparation for the general meeting of shareholders, the board of directors (supervisory board) is obliged to determine: the form and text of the voting ballot in case of voting by ballots, the wording of decisions on the agenda items of the meeting, which must be sent in electronic form by nominal holders registered in the register of shareholders; according to Art. 52 and 54 of the Law on Joint Stock Companies, in preparation for the general meeting of shareholders, the board of directors (supervisory board) is obliged to determine the e-mail address to which the completed ballots can be sent (Article 54), which must be indicated in the subsequent notice of the general meeting shareholders (Article 52);

a separate mechanism for electronic voting using the Internet ("evoting" $)^{30}$ has been introduced. The basis of this mechanism is set forth in

${ }^{30}$ Here it is necessary to make terminological clarifications. We see the use of the term "e-voting" to describe electronic voting in a number of modern works [Magdalinskaya Yu.V., 2020]. However, in a number of cases, when the authors want to emphasize the remote nature of electronic interaction, a different term is introduced - "i-voting" [Ba- 
paragraph 4 of Art. 60 of the Law on Joint Stock Companies, which stipulates that the charter of a joint stock company may provide a filling out an electronic form of ballots on a website, the address of which is indicated in the notice of the general meeting of shareholders. However, from a legal point of view, these prescriptions are presented in an extremely careless manner; they make up the second sentence of this paragraph (the paragraph consists of four sentences in total), which looks like a separate norm that does not create unity with the first sentence, which has nothing to do with the e-voting mechanism at all. ${ }^{31}$

To implement the e-voting mechanism, Art. 54 of the Law on Joint Stock Companies provides that the board of directors (supervisory board) of a joint stock company is obliged to determine the address of the, where the electronic form of ballots can be filled out; Art. 52 of the Law on Joint Stock Companies indicates that the notice of the general meeting must indicate the address of the site on which the electronic form of ballots can be filled out, if such a method of filling out ballots is provided for by the charter of the joint stock company. It should be noted that these legal norms do not directly specify which websites are in question, i.e., when adopting the relevant provisions, the legislator adhered to a dispositive approach;

Art. 60 of the Law on Joint Stock Companies provides that filling out the electronic form of ballots on the website can be carried out by shareholders during the general meeting of shareholders, if they have not exercised their right to participate in such a meeting in another way. At the same time, it is not indicated that this possibility exists only if such a form of electronic voting is provided for by the charter, but, apparently, this is still one of the conditions for using such an option, although the law could have indicated this more clearly;

taeva B.S., 2020: 76]. The appearance of the latter term is not accidental, the fact is that the special literature on the use of electronic methods of expression of will in the electoral process indicates the differences between "e-voting" and "i-voting". The first is understood as "voting at stationary polling stations" ", but the second is actually" remote voting with the help of technical devices "[Fedorov V.I., 2020: 35].

${ }^{31}$ An attempt to make such a "bundle" was made by the Bank of Russia in a letter dated May 27, 2019 No. 28-4-1 / 2816, that "within the meaning of paragraph 4 of Article 60 of Law No. 208-FZ, filling out an electronic form of ballots by a person entitled to participate in the general meeting of shareholders, on the website, the address of which is indicated in the notice of holding the general meeting of shareholders, can only be provided for by the charters of companies that send or deliver ballots, or publish ballots in accordance with paragraphs 2 and 3 of Article 60 of Law No. 208-FZ “... Such an explanation has already received well-deserved criticism in doctrunee, where it is noted that such an interpretation significantly narrows the possibilities of holding general meetings using electronic technologies [Medvedeva T.M., Azimova L.V., 2020: 72]. 
e) other cases of electronic interaction have been established:

Art. 41 of the Law on Joint Stock Companies was supplemented with a provision stating that an application for the acquisition of the offered securities of a person with a preemptive right may be sent to the registrar of the joint stock company in the form of an electronic document, if this is provided for by the rules for maintaining the register. It is also indicated that such rules may provide for the possibility of signing an electronic document with a simple or unqualified electronic signature;

in Art. 76 of the Law on Joint Stock Companies, an amendment has been made, according to which the requirement to purchase shares of a shareholder registered in the register of shareholders of the company, or the withdrawal of such a requirement is presented to the registrar of the company by mailing or handing over against signature a written document signed by the shareholder, and if this is provided for by the rules on maintaining the register, also by sending an electronic document signed with a qualified or simple electronic signature.

In 2016, the Bank of Russia in the "Main directions of development of the financial market of the Russian Federation for the period 2016-2018" among the measures that should ensure the achievement of the goals set by the document calls "stimulating the use of electronic interaction mechanisms in the financial market."

In 2016, a document was adopted aimed at implementing the amendments made to the Law on the Securities Market in June 2015 in terms of organizing electronic interaction between the issuer, the joint-stock company and the central depository. (Decree of the Bank of Russia. June 1, 2016. No. 546-P "On the list of information related to the exercise of rights on securities provided by issuers to the central depository").

Amendments to the Law on Joint Stock Companies, introduced by the Law of June 29, 2015 No. 210-FZ, in terms of expanding electronic forms of interaction when convening, preparing and holding a general meeting of shareholders, were developed in the Regulation of the Bank of Russia No. 660 of November 16, 2018 -P "On General Meetings of Shareholders". ${ }^{32}$ In par-

32 The Bank of Russia commented on the creation of this document as follows: "Based on new changes in legislation, as well as taking into account changes in the development of information technologies in order to ensure the comfortable exercise by shareholders of their rights, a Bank of Russia normative act has been adopted that establishes additional requirements for the preparation, convocation and holding general meeting of shareholders. The regulatory act defines the specifics of participation in the general meeting of shareholders whose rights to shares are accounted for by a nominee holder, voting by 
ticular, in addition to the provisions that retained the previous regulation in relation to electronic interaction, the following important norms appeared:

a proposal for the agenda of the general meeting and the requirement to hold an extraordinary general meeting are recognized as received if they were received from shareholders in the form of an electronic document of a nominee registered in the register of shareholders of the company (para 2.2);

the date of receipt of the proposal on the agenda of the general meeting or the requirement to hold an extraordinary general meeting of shareholders was determined, including if several shareholders act jointly, sent in the form of an electronic document (clauses 2.5, 2.12, 2.13, 2.16, 2.17);

para 2.18 established the possibility of applying the candidate's consent to be nominated to the governing body of the joint-stock company "in the form of electronic images of documents (documents on paper, scanned with preservation of their details)";

para 3.9 establishes the period within which the joint-stock company must send to the registrar the wording of decisions on the agenda items of the shareholders meeting, as well as voting ballots for the purpose of sending them in electronic form to nominees in accordance with the rules established by Art. 8.9 of the Law on the Securities Market;

para 4.3 establishes that if the company's charter provides for the filling out the electronic form of ballots by a person entitled to participate in the general meeting on the Internet site, the website of the joint-stock company itself or its registrar or central depository can be used..$^{33}$ As can be seen from the above rule, an act of the Bank of Russia, in contrast to the provisions of the Law on Joint Stock Companies (Article 52.54), restricts sites that can be used in terms of the e-voting mechanism; ${ }^{34}$

filling out an electronic bulletin on the Internet, as well as the procedure for jointly exercising by shareholders their rights "(see: Annual report of the Bank of Russia for 2018. App. 04/26/2019, p. 189. Available at: http://www.cbr.ru/collection/collection/file/19699/ ar_2018.pdf (accessed: 7.02.2021)

${ }^{33}$ At the same time, as noted in one of the letters of the Bank of Russia, "the specified norm does not exclude the possibility of the simultaneous use for the specified purposes of more than one of the specified sites on the Internet. At the same time, based on clause 4.7 of the Regulations, if the general meeting is held with the possibility of filling out the electronic form of ballots on the website, registration of persons participating in the general meeting in this way is carried out on the website on which the electronic form of the bulletin is filled in "(see: Letter of the Bank of Russia. May 27, 2019. No. 28-4-1 / 2816 // SPS Consultant Plus.

34 The purpose of such a limitation is not clear, researchers note this approach excludes use of the official sites of depositories - nominal holders [Medvedeva T.M., Azimova L.V., 2020: 73]. 
para 4.7, 4.8, 4.11 establish the specifics of registration and attendance at the meeting. In particular, para 4.7 establishes the peculiarities of registration of persons participating in the general meeting, if the general meeting is held with the possibility of filling out an electronic form of ballots: registration of persons participating in the general meeting in this way is carried out on a website, where the electronic ballot form is filled out. ${ }^{35}$ Para 4.8 determines that persons entitled to participate in the general meeting, whose electronic form of ballots has been is filled out on the Internet no later than two days before the date of the general meeting, have the right to attend the meeting. Para 4.11 defines the specifics of identification, authorization, registration of persons participating in the general meeting without being present at the venue of the meeting with the possibility of filling out an electronic form of ballots on the Internet site;

in accordance with para 4.13 , before the beginning discussion on the election of the body of a joint-stock company, whose members are elected by cumulative voting, information on the number of votes cast for each of the candidates elected to the body of the company must be brought to the attention of the persons present at the general meeting of shareholders by cumulative voting, using ballots that have been received or the electronic form of which is filled out on the website, no later than two days before the date of the general meeting;

para 4.33 requires the e-mail address to be reflected in the minutes of the general meeting to which the completed voting ballots were sent during the general meeting both in person and in absentia, if voting on the issues included in the agenda of the general meeting could be carried out by sending it to the company completed ballots. If the general meeting was held with the possibility of filling out electronic ballots on the Internet also the address of such a site has to be disclosed.

One of the directions for the development of electronic interaction between the joint-stock company and the shareholder was the adoption of the Bank of Russia directive No. 5182-U. June 28, 2019 "On additional requirements for the provision of documents or copies of documents by joint-stock companies." This document (par. 11) provides for the possibility of a shareholder sending a request for information by e-mail, if this is provided for by the charter or internal document of the joint stock company.

The last document in the "pre-COVID" era on issues of interest to us was the decree of the Government of the Russian Federation of January 17, 2020

${ }^{35}$ See also: Letter of the Bank of Russia. May 27, 2019 No. 28-4-1 / 2816. 
No. 19-r. ${ }^{36}$ With this document, the plan "Transformation of the business climate", adopted in 2019, was supplemented by a provision on the need to prepare proposals (for example, in the form of a report to the Government) on providing "joint stock companies with the opportunity to hold a general meeting of shareholders online, which will allow using electronic services to organize the broadcast of speeches of the company's leaders, ask them questions, declare a quorum and results of absentee voting and carry out a remote vote via the shareholder's personal account.

There is no information on the implementation of this item of the plan in publicly available sources; at the same time, the corresponding item was later not included in the new version of the Action Plan for the implementation of the mechanism for managing systemic changes in the legal regulation of entrepreneurship "Transformation of the business climate", "Corporate governance, special administrative regions, bankruptcy procedure, appraisal activities". 37

As can be seen from the previous presentation, by the end of the 2010s. a complex of regulatory provisions has developed that regulate the use of electronic means of communication for interaction between a joint-stock company and a shareholder, both directly and through intermediaries professional participants in the securities market.

This complex was formed under the influence of Russian and Western experience in using electronic technologies in elections, recommendations of international organizations on organizing electronic remote interaction of corporations and their participants, as well as program and other official documents setting goals and objectives in the field of creating electronic government and improving corporate governance.

The aforementioned complex includes provisions constituting legislation on joint stock companies and legislation on the securities market; it is represented by two federal laws (the Law on Joint Stock Companies and the Law on the Securities Market), acts of the Bank of Russia, as well as separate clarifications of the regulatory nature of the Bank.

As a result, in the "pre-COVID" era, new (electronic, remote) forms of interaction between shareholders and joint-stock companies began to be used; the necessary amendments were made to the charters of the largest public joint stock companies; to provide new opportunities, a range of

36 This document amended the order of the Government of the Russian Federation. January 17, 2019. No. 20-p "On the approval of the plan" Transformation of the business climate.

37 Approved by order of the Government of the Russian Federation. July 2, 2020. No. 1723-p. 
services [Chekhovskaya S.A.,2018] ; [Elnikova E.V., 2020] began to form, created and provided by the central depository, ${ }^{38}$ professional participants in the securities market (registrars) ${ }^{39}$ and IT companies; the number of shareholders who voted using the Internet grew every year. ${ }^{40}$

There are, nevertheless, some critical comments to this quite favorable view. First, let's note that:

during the specified period, regulation did not develop in terms of the use of electronic forms of interaction in other corporations, as well as in various civil law communities (with rare exceptions);

with the exception of the Corporate Governance Code, no rules have been created for the activities of other collegial bodies of a joint stock company, except for the general meeting of shareholders (board of directors, collegial executive bodies and other bodies).

During this period, the legal regulation of the use of special technical means of counting votes, various electronic forms of interaction between participants in the electoral process (filing an application for inclusion in the voter list at the location via the "Mobile Voter" mechanism, remote electronic voting), ${ }^{42}$ as well as meeting participants (including voting) for

38 Available at: https://www.e-vote.ru/ (accessed: 7.02.2021)

39 A description of such interaction using the services "personal account of the issuer" and "personal account of the shareholder" on the example of one of the largest Russian registrars JSC “DRAGA” is given in [Lanskov D.P., Danilova S.A., 2019: 14-17].

${ }^{40}$ Complete statistics for Russia does not exist, however, in some works, sample statistics are provided for some of the largest issuers - joint stock companies [Bataeva B.S., 2020: 83].

${ }^{41}$ The exceptions are: - development since 2014 of the institution of absentee voting of owners of premises in apartment buildings using information systems - the state information system of housing and communal services (Articles 44, 44.1, 47.1 of the Housing Code of the Russian Federation. (Federal Law of July 21, 2014 No. 263- Federal Law "On Amendments to Certain Legislative Acts of the Russian Federation in Connection with the Adoption of the Federal Law" On the State Information System of Housing and Communal Services"; Federal Law of June 29, 2015 No. 176-FZ" On Amendments to the Housing Code of the Russian Federation "In this regard, normative acts of the constituent entities of federation were also adopted (for example, the order of the Moscow Department of Information Technologies of February 27, 2018 No. 64-16-87 / 18 "On Approval of the Rules for the Use of the Active Citizen Information System" implementation of the pilot project "Electronic House")); the possibility of using these information systems to manage housing and housing construction cooperatives and homeowners' associations (Articles 113, 135 of the Housing Code of the Russian Federation). However, it is impossible to call such regulation clear, and in relation to the last three indicated subjects, the Housing Code contains only a general indication without any detailed description.

${ }^{42}$ See: Federal Law No. 93-FZ of July 21, 2005 "On Amendments to the Electoral Legislation of the Russian Federation”; Federal Law of May 29, 2019 No. 103-FZ "On the 
the defense of dissertations for academic degrees. ${ }^{43}$ That is, both the use of special technical means for counting and processing ballots and electronic forms of interaction were in great demand in public relations. However, with all the similarity of the problems being solved (increased activity, cheaper process, etc.), we see no single political and legal attitudes to public and private relations, no single approaches to solving problems (even the terminology used is different).

Secondly, the established regulation cannot be considered optimal:

the technical imperfection of these legal regulations should be noted. They are unnecessarily complicated and do not provide answers to some important questions. This is partly due to the fact that the legislator tried to include electronic forms of interaction in the existing procedural norms of the Law on Joint Stock Companies, without making sseparate articles devoted to that;

the configuration of the specified regulations is not fully optimal (separation of norms between two laws, between a federal law and a decree); noteworthy in this configuration is the presence of clarifications on the part of competent executive body - which is a consequence of the abovementioned technical imperfection of the norms;

the legislator passes over in silence the issues of using electronic technologies for voting by shareholders at the meeting in person, paying special attention only to remote interaction procedures. This idea can be expressed in another way: the legislation on joint-stock companies does not distinguish between cases of using electronic devices for interaction (voting, first of all), which can be at the place of the meeting in person and remote voting using electronic devices.

\footnotetext{
Experiment on the Organization and Implementation of Remote Electronic Voting at the Elections of Deputies of the Moscow City Duma of the Seventh Convocation"; Resolution of the CEC of Russia. July 6, 2011. No. 19/204-6 "On the procedure for using technical means of counting votes - complexes for processing ballots in 2010 at elections and referendums held in the Russian Federation"; Resolution of the CEC of Russia. September 7, 2011. No. 31 / 276-6 "On the Procedure for Electronic Voting Using Complexes for Electronic Voting in Elections"; The procedure for remote electronic voting in the by-elections of deputies of the State Duma of the Russian Federation of the seventh convocation in singlemandate constituencies on September 13, 2020, approved by the decree of the Central Election Commission of July 27, 2020 No. 261 / 1924-7 and a number of other regulations.

${ }^{43}$ Within the framework of local regulations of organizations that have received the right to independently award academic degrees in accordance with Federal Law No. 148FZ of May 23, 2016 "On Amending Article 4 of the Federal Law" On State Scientific and Technical Policy".
} 
It should also be noted that the dissemination of the new rules proceeded with difficulty, which is clearly seen in the reviews of the corporate governance practice of the Bank of Russia in terms of the recommendations of the 2014 Corporate Governance Code on the need to ensure remote access of shareholders to the shareholders' meeting (principle 1.1.6).

The Review of corporate governance practices in Russian public companies, compiled on the basis of annual reports for $2016,{ }^{44}$ does not provide detailed data, but only notes that the relevant principles turned out to be the most difficult to comply with "as in 2015" (analysis of the 2015 Review, see above).

The Review of Corporate Governance Practices in Russian Public Companies, prepared on the basis of annual reports for $2017,{ }^{45}$ provides a more detailed analysis. In particular, it is noted that the relevant recommendations "are observed only by some companies". 46

The review of corporate governance practices in Russian public companies for $2018^{47}$, is similar in conclusions to the previous ones - it is also noted that "many companies still use traditional forms and tools for holding general meetings of shareholders". The review discloses the reasons of it. ${ }^{48}$ However,

${ }^{44}$ See: Review of corporate governance practices in Russian public companies... P. 16. Available at: http://www.cbr.ru/collection/collection/file/24045/review_27122017.pdf (accessed: 7.02.2021)

${ }^{45}$ See: Review of corporate governance practices in Russian public companies... P. 1718. Available at: http://www.cbr.ru/collection/collection/file/24044/review_04122018.pdf (accessed: 7.02.2021)

${ }^{46}$ The following reasons for this state of affairs, mentioned by joint-stock companies, were noted: the lack of provisions in the charters on the possibility of remote participation in voting; lack of technical capability for remote voting; impossibility to ensure the identification of shareholders; significant financial costs for the technical support of remote voting; low activity of minority shareholders in general meetings of shareholders over the past years; low level of information literacy and technical skills among certain groups of minority shareholders; the habit of shareholders to take part in a meeting "the old fashioned way" (sending filled-out ballots or attending meetings in person). See: Review of corporate governance practices in Russian public companies (hereinafter referred to as the Review) gor 2018. P. 24. Available at: http://www.cbr.ru/collection/collection/file/25363/ review_29112019.pdf (accessed: 7.02.2021)

47 See: Overview of corporate governance practices in Russian public companies based on 2018 annual reports. P. 24. Available at: http://www.cbr.ru/collection/collection/ file/25363/review_29112019.pdf (accessed: 7.02.2021)

48 "As the reason for the society, they usually cite the insufficient level of information and technical literacy of certain groups of shareholders, the lack of relevant requests from the shareholders. Some companies also cite as reasons for refusing to use telecommunications to provide shareholders with the opportunity to remotely participate in general meetings, the high cost of relevant technologies and services, the lack of technical capacity for the company to implement remote access technologies." 
new aspects appear in the position of the Bank of Russia: it notes the need to consider the issues of using telecommunications in order to provide shareholders with remote access on a periodic basis; ${ }^{49}$ an interesting "prediction" was made as to why such methods will become more widespread over time: “The composition of the company's shareholders changes over time and a new generation of investors is coming to replace them, for whom remote forms of participation in the meeting may be much more convenient and preferable than traditional ones. In addition, it is necessary to take into account the rapid development of information technology, including the solutions proposed for remote participation in shareholders' meetings" ${ }^{50}$

In the Review for $2019^{51}$ the Bank of Russia notes a positive trend in the implementation of Principle 1.1.6 "over the entire monitoring period". The following is noted: "if at the end of 201514 companies (17\%) announced the introduction of principle 1.1.6 of the Code into their corporate practice, then in 2019, according to self-assessment, 31 companies (51\%) fully comply with this principle, one of the criteria which is the consideration by the board of directors of the issue of providing shareholders with remote access to general meetings."

\section{COVID-19 as a trigger for the transition to telecommuting interaction of participants in corporate governance}

The rapid and widespread spread of coronavirus infection (COVID-19) both in Russia and around the world has led to the adoption of restrictive

49 "The annual consideration by the board of directors of the issue of using telecommunications in order to provide shareholders with remote access to participate in general meetings of shareholders is important to create the most favorable conditions for shareholders to exercise their rights. Of course, the board of directors should balance the need to introduce technologies for remote participation in the general meeting of shareholders with both the needs of shareholders and the economic capabilities of the company, but this does not mean that the need to introduce such technologies should not be considered on a periodic basis."

50 "The Bank of Russia believed that" adherence to principle 1.1.6 of the Code will enable the board of directors to respond in a timely manner to new needs and requests from shareholders, to apply new technologies in the procedures for interacting with them, thereby contributing to the creation of the most favorable conditions and opportunities for shareholders to participate in management society and increasing the attractiveness of society in the eyes of existing and potential investors". See: Overview of corporate governance practices in Russian public companies based on 2019 annual reports. P. 13. Available at: http://www.cbr.ru/collection/ collection/file/31741/review_corp_14122020.pdf (accessed: 7.02.2021)

${ }^{51}$ Ibid. 
measures by public authorities in many countries. In Russia, restrictions were formed at two levels: federal ${ }^{52}$ and regional. ${ }^{53}$

The relevant measures were varied, formulated using different concepts, ${ }^{54}$ the main ones of which are:

"ban" (mass events, etc.);

"temporary suspension" (events with full-time attendance; attendance by citizens of public events, etc.);

the imposition of additional responsibilities (use of personal protective equipment; "compliance with the regime of self-isolation"; compliance with measures for "social distancing", etc.);

restriction of movement of citizens;

suspension of the validity of the right ("suspension of the validity of some public transport tickets", etc.).

The restrictions imposed immediately made it clear that corporate actions such as meetings of shareholders in person would be impossible or extremely difficult in a to hold certain period.

The restrictions imposed immediately made it clear that corporate actions such as meetings of shareholders in person would be impossible or extremely difficult in a certain period. To solve the problem, the state was forced to make special legal decisions in the form of extraordinary federal laws; $; 5$

${ }^{52}$ For example, see: Federal Law of April 1, 2020 No. 99-FZ "On Amendments to the Code of Administrative Offenses of the Russian Federation"; Decree of the President of the Russian Federation of April 2, 2020 No. 239 "On measures to ensure the sanitary and epidemiological well-being of the population on the territory of the Russian Federation in connection with the spread of a new coronavirus infection (COVID-19)"; Decree of the President of the Russian Federation of April 28, 2020 No. 294 "On the extension of measures to ensure the sanitary and epidemiological well-being of the population in Russia in connection with the spread of a new coronavirus infection (COVID-19)"; Presidential Decree of May 11, 2020 No. 316 "On determining the procedure for extending measures to ensure the sanitary and epidemiological well-being of the population in the regions of the Russian Federation in connection with the spread of a new coronavirus infection (COVID-19)."

53 The most famous example, which served as a benchmark for other regions of Russia, is the Decree of the Mayor of Moscow. March 5, 2020 No. 12-UM "On the introduction of a high alert regime."

${ }^{54}$ In the Presidential Decree of April 2, 2020, they are generally designated as "restrictive and other measures."

${ }^{55}$ For an overview of selected measures, see also the Bank of Russia's Review of Corporate Governance Practices in Russian Public Companies for 2019. P. 8-9. Available at: 
Art. 2 of the Federal Law of March 18, 2020 No. 50-FZ "On the acquisition by the Government of the Russian Federation from the Central Bank of the Russian Federation of ordinary shares of the public joint stock company Sberbank of Russia" (hereinafter - the Law of March 18, 2020 No. 50-FZ);

Federal Law of April 7, 2020 No. 115-FZ "On Amendments to Certain Legislative Acts of the Russian Federation in terms of unifying the content of annual reports of state corporations, public companies, as well as in establishing the specifics of regulating corporate relations in 2020" (hereinafter the Law of April 7, 2020 No. 115-FZ). Some of the provisions of this law were clarified by the letter of the Bank of Russia of April 9, 2020 No. IN-06-28 / 54 "On holding annual general meetings and distribution of profits in 2020";

Federal Law of July 31, 2020 No. 297-FZ "On Amendments to Certain Legislative Acts Regarding the Unification of the Content of Annual Reports of State Corporations, Public Companies, as well as Establishing the Specifics of Regulation of Corporate Relations in 2020".

The technical side of these decisions in some cases left much to be desired, ${ }^{56}$ but in fairness it is necessary to take into account the extraordinary nature of these legal decisions caused by extraordinary circumstances, as well as the need to adopt new regulation in a short time.

The main provisions of the proposed measures were to change the timing of annual general meetings of shareholders in 2020 and remove restrictions on all decisions by annual general meetings in absentia (Articles 11 and 12 of the Law of April 7, 2020 No. 115-FZ).

It is noteworthy that none of these laws attempted to stimulate the use of electronic remote forms of interaction between participants in corporate relations (a shareholder and a joint-stock company, members of collegial management bodies) to overcome emergencies and / or create a new one, and / or improve current regulation. However, the objective circumstances that have developed in the context of the spread of COVID-19 and restrictive measures aimed at preventing its spread have led to a multiple

\footnotetext{
http://www.cbr.ru/collection/collection/file/31741/review_corp_14122020.pdf (accessed: 7.02.2021)

${ }^{56}$ For example, if Art. 2 of the Law of March 18, 2020 No. 50-FZ established a general rule that a meeting of shareholders, the agenda of which includes the issues specified in paragraph 2 of Art. 50 of the Law on Joint Stock Companies, in 2020, by decision of the board of directors of a joint stock company could be held in the form of absentee voting, then Art. 11 of the Law of April 7, 2020 No. 115-FZ has already suspended until December 31,2020 inclusively, the effect of this provision.
} 
increase in the use of remote electronic forms of interaction during general meetings of shareholders in $2020 .^{57}$

It is quite obvious that the wide experience of using remote electronic interaction received by joint-stock companies and their shareholders in 2020 (we do not exclude that restrictions will remain in 2021) will never return the previous idea of corporate actions as meetings held by a groupof people gathering in one place and at the same time, and using the raising of their hands for the expression of their will. And the point is not only that this allows corporate actions to be carried out in a difficult epidemiological situation, the point is different: the modern development of technologies has led to what - remote electronic - interaction is - it is convenient for participants in corporate relations and much less costly for them.

Electronic technology, remote meeting participation, fully virtual meetings are the future of corporate action. Therefore, it is advisable to look at the essence of electronic and remote forms of interaction, at what legislative initiatives exist today in this area and at how we could institutionalize these forms in our legislation.

\section{On electronic and remote forms of interaction in essence and on the prospects for the development of these forms in corporate law}

An analysis of the specialized literature provides a basis for the conclusion that the use of electronic and remote technologies in corporate governance is partly a consequence of the evolution of electoral technologies. V. Fedorov notes that "the study of the world experience in voting automation makes it possible to identify similar and special characteristics of electoral devices, different principles of their operation, which indicate the existence of three large projects for the automation of voting and vote counting: mechanical (IV century BC - 1960-e years); electronic stationary (1860s - present); electronic distance (1996 - present)" [Fedorov V.I., 2020: 40].

57 There is no complete statistics on this issue, however, it is the multiplicity of growth that is shown by the data provided in the publicly available information materials of the Central Securities Depository - the presentation "Service of electronic voting e-voting: advantages of use in new conditions", made on December 22, 2020.Available at: https:// www.nsd.ru/upload/docs/conf/2020-12-22/preim.pdf(accessed 7.02.2021); available at: https://www.nsd.ru/publications/meropriyatiya/vebinary/vebinar-dlya-klientov-nrd-servis-elektronnogo-golosovaniya-e-voting-v-novykh-usloviyakh-itogi-goda-i/ (accessed: 7.02.2021) 
In part, the use of electronic technologies for interaction between shareholders and joint-stock companies in Russian legislation, as noted above, is also following the examples of Western legal regulation (Directive 2007/36 / EU; Directive (EU) 2017/828).

If we analyze the issue of electoral electronic technologies, it will be obvious that one cannot equate the concept of "remote" voting and "electronic" voting. Electronic voting can be carried out at the place of the elections, but using special technical devices. Remote voting, on the other hand, is the vote of a person who is not present at the polling station. It can be assumed that such a distinction should be at the heart of modern legal decisions when changing the legislation on elections in Russia. ${ }^{58}$ However, legal decisions regarding remote electronic voting cannot be called finalized yet, suffice to say that there are, for example, several definitions of the electronic voting in relevant legal acts. ${ }^{59}$

It is obvious that further development will follow the path of using remote electronic voting, which is clearly indicated by the Main Directions of Development of the Russian State Automated System "Elections" (Выборы) until 2022. One of the tasks that must be implemented by 2022, this document refers to the creation of a digital platform, on the basis of which the technical possibility of conducting remote electronic voting us-

58 The Federal Law of June 12, 2002 No. 67-FZ “On Basic Guarantees of Electoral Rights of Citizens of the Russian Federation" provides a separate definition (Art. 2) for "electronic voting" (as voting without using a paper ballot, but with using technical means) and for "remote electronic voting" (voting without using a paper ballot but using special software".

59 One of the definitions is given in the Federal Law of June 12, 2002 No. 67-FZ "On the Basic Guarantees of the Electoral Rights of Citizens" (Article 2), the other - in the Federal Law of May 23, 2020 No. 152-FZ " On conducting an experiment on the organization and implementation of remote electronic voting in the city of Moscow "; there are also relevant definitions in individual resolutions of the CEC of Russia in 2014 (for example, see: The procedure for remote electronic voting in the by-elections of deputies of the State Duma of the Russian Federation of the seventh convocation in single-mandate constituencies on September 13, 2020", approved by the CEC resolution of 27 July 2020 No. 261 / 1924-7 (para 1.2). In terms of content, they are similar, but there are some differences.

It is curious to note that similar processes are going on in relation to legislation on science in terms of holding meetings of dissertation councils, although they use their own terminology - "remote interactive mode ... subject to audiovisual contact with meeting participants" (see: Resolution of the Government of the Russian Federation of May 26, 2020 No. 751 "On the specifics of holding meetings of councils for the defense of dissertations for a scientific degree during the period of measures aimed at preventing the spread of a new coronavirus infection in the Russian Federation" (expires on August 1, 2021); Resolution of the Government of the Russian Federation of 20 March 2021 No. 426 "On Amending Certain Acts of the Government and invalidating Resolution No. 751 of May 26, 2020). 
ing a personal account is implemented (with the user's identification on the ESIA - Unified identification and authentication system) ${ }^{60}$

Nevertheless, the state retains the possibility of another version of electronic voting - using special technical devices at polling stations (researchers talk about different options, for example, the technology of using complexes for processing ballots). ${ }^{61}$

Strictly speaking, the development of legislation on electronic and remote forms of interaction between participants in corporate relations could go hand in hand with the development of electronic stationary and remote electronic technologies in elections and during meetings of dissertation councils. However, as we saw from the description given above, there is no such correlation.

We see a clear trend towards increased use of electronic interaction, which was set in the framework of electoral and science legislation, but we do not see similar patterns. There is a difference in terminology, in addition, as already noted, the legislation on joint stock companies completely ignores the issue of using electronic devices when voting at a meeting of shareholders in person. The main emphasis was initially placed on electronic remote forms of interaction. The Bank of Russia in one of its materials, "Report on the assessment of the actual impact of the implemented proposals. Corporate Governance " $(2016)^{62}$ - very clearly described the needs for the implementation of the proposal to introduce electronic voting: providing the possibility of remote voting; optimization of operating costs for organizing the voting process; increasing the transparency of the voting mechanism; additional protection against fraudulent voting.

In another document - "Report for public consultations. On approaches to stimulating the activity of shareholders and investors to participate in the management of Russian public joint-stock companies "(2017), ${ }^{63}$ the Bank made it very clear that increased attention to remote forms of inter-

${ }^{60}$ Federal State Information System "Unified system of identification and authentication in the infrastructure of state and municipal services in electronic form."

${ }^{61}$ See, for example: Resolution of the Central Election Commission of the Russian Federation of January 17, 2018 No. 129 / 1072-7 "On the use of technical means of counting votes - complexes for processing ballots during voting in the elections of the President of the Russian Federation" // SPS Consultent Plus.

${ }^{62}$ Available at: http://www.cbr.ru/content/document/file/84700/ofv_corp_gov.pdf (accessed: 9.02.2021)

${ }^{63}$ Available at: http://www.cbr.ru/content/document/file/50695/consultation_paper_170925.pdf_(accessed: 9.02.2021) 
action was caused by the need to increase the involvement of shareholders in the management of society. ${ }^{64}$

At the same time, it should be noted that the legislator still treats innovations in the regulation of electronic forms of corporate interaction with extreme caution - suffice it to say that all the are reduced to the regulation of hybrid meetings, when electronic forms of voting established by law (sending a message by e-mail; giving instructions through a nominee in electronic form; filling out a ballot on the website) are only additional opportunities for holding a meeting in person or absentee voting. Purely virtual or digital meetings - when all their participants interact electronically and remotely, the law does not provide.

From our point of view, the time has come to revise the current legislation in order to systematically describe the issues of electronic (including remote) interaction of participants in corporate relations.

There are now several initiatives in this area.

First, the draft amendments to the Federal Law "On Joint Stock Companies" in terms of creating the possibility of holding general meetings of shareholders in the form of a meeting by means of joint remote presence to discuss agenda items and make decisions on issues put to a vote, using information and communication technologies without specifying the venue "(project ID 02/04/09-20/00107789). ${ }^{65}$ This draft proposes that in addition to a meeting in the form of joint presence of shareholders at the place of

64 "It should be noted that in addition to special rules of law and 'soft regulation' aimed at stimulating the participation of shareholders in the management of the company, the company itself and its board of directors also have certain resources to increase the involvement of shareholders in the management of the company and must use them. The correct policy of interaction and effective channels of communication with shareholders can have a significant impact on the level of participation of minority shareholders in general meetings and their adoption of truly balanced decisions that meet the interests of both the shareholders themselves and the society as a whole. To do this, the company needs not only to simplify as much as possible the access of shareholders to the information on the basis of which decisions are made, and to make the process of participation in the general meeting as comfortable as possible for minority shareholders, for example, through the widespread use of modern information technologies, but also to create in shareholders a sense importance of their participation through the understanding that their opinion is taken into account by society when solving key problems and that they really influence the decision-making process in society and participate in its governance. A further consistent reduction in the costs associated with investor access to services that make it easier for investors to participate in the management of joint stock companies, in particular, a decrease in the cost of electronic voting on general meeting of shareholders, could potentially have a positive impact on the level of activity of Russian shareholders."

${ }^{65}$ Available at: https://regulation.gov.ru/projects\#npa=107789 (accessed: 9.02.2021) 
the meeting, a form of "joint remote presence" is also introduced; however, various hybrid forms of e-remote participation also remain permissible.

Secondly, the draft amendments to the Federal Law "On Joint Stock Companies" and certain legislative acts of the Russian Federation", introduced by the Deputy of the State Duma V.M. Reznik. ${ }^{66}$ This project is less radical than the first in terms of innovations. The main innovation is the introduction of the concept of a "general meeting of shareholders with remote participation" ("a general meeting of shareholders of a company in the form of a meeting can be held using information technologies that make it possible to remotely participate in it, discuss agenda items and make decisions on issues put to a vote"). A distinctive feature of this project is the introduction of a special article for such meetings - "Features of preparation, convocation and holding a meeting with remote participation."

From our point of view, both legislative initiatives, despite some of their advantages, cannot be called optimal.

First of all, it should be noted that the proposed approach, when only the legislation on joint stock companies is changed, is incorrect. The problem of remote electronic participation in meetings is a problem for all legislation on legal entities, and not only corporate, but also unitary (there are also examples of the participation of several founders, as well as collegial bodies), and if you look more broadly,this is a problem that is relevant for all private legal entities. Accordingly, the changes should be of a systemic nature, which implies, first of all, a change in the provisions of the Civil Code of the Russian Federation both in terms of legal entities and in terms of civil law societies. Otherwise, we will receive non-systemic changes. And the risks are obvious here:

one part of the corporate legislation (legislation on business companies) will be changed, and the other part - in relation to business partnerships, farms - legal entities, cooperatives, non-profit organizations - will remain unchanged, and the participants of such corporations will be deprived of the opportunity to use information technologies in their activities;

there will be unreasonable differences in terms of the concepts used and legal means. And the risks of this are already visible. So, in 2020, the Government of the Russian Federation was instructed (following the meeting of the Council for the Development of Local Self-Government on January 30,2020$),{ }^{67}$ to amend legislation in order to provide an opportunity for

\footnotetext{
${ }^{66}$ Available at: https://sozd.duma.gov.ru/bill/1059849-7 (accessed: 9.02.2021)

${ }^{67}$ Available at: http://www.kremlin.ru/acts/assignments/orders/62919 (accessed:
} 11.02.2021) 
citizens to send proposals on the agenda of the general meeting of homeowners in electronic form, and voting on these issues using a single digital platform.

This instruction was implemented by the adoption of the Decree of the Government of the Russian Federation of January 16, 2021 No. 9. This normative act established the possibility of voting in absentia by owners of premises in an apartment building using the "Single portal of state and municipal services". The possibility of using such a platform is, of course, a positive legal decision. However, the question arises: why is this opportunity offered only to residents of apartment buildings, and not to members of any corporations? It turns out that the owners of premises in apartment buildings will have the possibility of electronic remote voting using such a platform, and the participants of joint-stock companies will be deprived of such an opportunity, and for them the above draft laws imply other legal solutions. Interestingly, in the same year 2020, an instruction of a more general nature was issued - Pr-1726GS, clause 8b) (from the List of instructions following an expanded meeting of the State Council Presidium, held on September 28, 2020). ${ }^{68}$

In accordance with this instruction, the Government of the Russian Federation should create conditions for the transition mainly to document automation in the interaction of citizens registered on the specified portal, organizations and authorities, providing for the possibility of integrating with this platform the electronic document management systems of public authorities of the regions of the Russian Federation, local governments and organizations. In fact, the nature of the order makes it possible to form a single platform for voting by members of various corporations and civil law companies.

It is quite obvious that various political and legal impulses should be at least correlated with each other for the purpose of creating general conditions for remote electronic interaction of participants of various legal entities and civil law communities. The specific changes that are currently proposed by these projects (apparently, there will be other initiatives) will only lead to confusion in the legislation, the "ragged" nature of its changes, the designation of the same institutions by different terms.

In general, it seems to us idea of correlation between private law and public law regulation of electronic interaction is very rational. Of course,

${ }_{68}$ Available at: http://www.kremlin.ru/acts/assignments/orders/64273 (accessed: 11.02.2021) 
specifics of the electoral process and the defense of dissertations will remain, but the basis for such interaction will be common, the terminology will be unified; perhaps we will even have common services (you can also call them the buzzword "platforms") for such remote electronic interaction, which will undoubtedly facilitate the tasks of its participants. To implement this idea, however, a certain conceptual basis is needed, as well as a serious interdisciplinary scientific and expert study of the issue.

With regard to changes in corporate legislation in general and legislation on joint stock companies in particular, from our point of view, the most optimal approach would be the following:

making general changes to the Civil Code, which allow the use of electronic forms of interaction between participants (founders) of legal entities, as well as in the activities of any civil law communities; it is also necessary to secure the possibility of such interaction with other participants in corporate procedures (creditors, first of all), as has already been done in separate laws. Then a general draft law should be prepared, which would introduce systemic changes to individual laws, synchronized in the general $\operatorname{logic}$

Civil Code and other special laws should assume the possibility of:

information electronic exchange on various grounds (notification of a meeting (meeting), information on the issues under consideration by electronic means, etc.);

use:

virtual meetings; here, the concept of "joint remote presence" proposed by one of the indicated projects is quite suitable, although variants are also possible; at the same time, such a decision requires careful regulation, and, possibly, at the first stage, special regulation by bylaws, including in the form of a legal experiment;

various types of voting at hybrid (mixted) meetings, when some of the participants are present in person, including remotely (online), and some participate in absentia (including using electronic interaction): electronic stationary voting; remote presence (participation and voting); remote electronic absentee voting;

the holding of hybrid meetings should be regulated in detail in each special law that will provide for it; at the same time, the possibility of using electronic stationary voting may be provided for use by the charter of any legal entity with a description of how specifically (with the use of what 
technical means) it is carried out; specific civil law communities will also require special regulation;

remote electronic absentee voting can be carried out during hybrid (mixed) meetings;

in the form of filling out electronic bulletins on specialized electronic resources (platforms);

in the form of sending the voting results by e-mail;

in the form of voting through the intermediary system (what is called the e-proxy voting mechanism);

for various legal entities, differentiated rules for remote electronic absentee voting may be provided - it is obvious that the last option - by the e-proxy voting mechanism - is, rather, for joint stock companies in which there is a system of intermediaries - nominee holders. Such a complex model implies the need for a special description of the procedure for registering and accounting for votes, which, again, will differ for different types and types of legal entities;

public joint stock companies must by law (and not simply because of such a possibility in the charter) provide the possibility of holding both fully virtual meetings and mixed (hybrid) meetings of shareholders. At the same time, the Law on Joint Stock Companies requires a complete revision of that part of it that regulates the preparation and conduct of meetings, with the aim of systematically describing both traditional meetings, mixed (hybrid) meetings, and virtual meetings. The method of making point changes, which is currently used, should be excluded, it leads to an unjustified complication of the normative material;

separate regulation requires the implementation of electronic forms of interaction for those shareholders who own shares of the joint-stock company in the form of digital financial assets, the release of which (digital financial assets certifying the rights to participate in the capital of the joint-stock company) became possible after the adoption of the Federal Law of July 31, 2020 No. No. 259-FZ “On digital financial assets and digital currency" (Art. 13).

\section{I国 References}

Alekseev R.A., Abramov A.V. (2020) Issues and prospects of using electronic voting and electoral blockchain technology in Russia and abroad. Grazhdanin. Vybory. Vlast, no 1, pp. 9-21 (in Russian) 
Antonov Ya.V. (2015) Development of legal regulation of electronic voting in Russia. Upravlenchekoye consultirovanie, no 5, pp. 63-71 (in Russian)

Bataeva B.S. (2020) Development of corporate governance using electronic voting services. Upravlencheskie nauki, no 2, pp. 74-87 (in Russian)

Chekhovskaya S.A. (2016) Modern development of corporate legislation. Pravo. Zhurnal Vysshey shkoly ekonomiki, no 2, pp. 74-86 (in Russian)

Chekhovskaya S.A. (2018) New contours of corporate law. Predprinimatelskoye pravo, no 3, pp. 31-41 (in Russian)

Druzhinin A. (2012) What is the most effective way to use electronic means of communication during GMS? Aktsionernyi vestnik, no 9, pp. 38-44 (in Russian)

Elnikova E.V. (2020) The use of digital technologies in voting at the general meeting of participants (shareholders) of a business company. Vestnik universita imeni O.E. Kutafina, no 7, pp. 60-67 (in Russian)

Fedorov V.I. (2017) Electronic voting: a fix idea or the foundation of future democracies? Grazhdanin. Vuboru. Vlast, no 1-2, pp. 170-185 (in Russian) Fedorov V.I. (2020) Projects of automation voting in a historical retrospective. Grazhdanin. Vuboru. Vlast, no 1, pp. 34-55 (in Russian)

Gabov A.V. (2020) Force majeure, coronavirus and decisions of authorities aimed at preventing its spread. Zakon, no 5, pp. 152-171 (in Russian)

Gontar S.G. (2019) Electronic voting - a new opportunity for citizens to participate in the formation of government bodies. Gosudarstvennaya vlast and mestnoye samoupravlenie, no 4, pp. 29-33 (in Russian)

Grigoriev A.V. (2020) Constitutional regulation of the use of modern information and communication technologies in the implementation of direct democracy institutions in Russia. Candidate of Juridical Sciences Summary. Moscow, 30 p. (in Russian)

Kersting N. (2007) Electronic voting and democracy in Europe. Politicheskaya nauka, no 4, pp. 123-144 (in Russian)

Khamutovskaya S. (2019) New voting technologies: foreign experience. Nauka i innovatsii, no 4, pp. 39-42 (in Russian)

Kolyushin E.I. (2020) Legal issues of remote electronic voting of voters. Constitutionnoye i municipalnoye pravo, no 2, pp. 25-30 (in Russian)

Kraakman R., Apmour J., Davies P., Enriques L., Hansmann H., Hertig G., Hopt K., Kanda H., Pargendler M., RingeW.-G., Rock E. (2017) The Anatomy of Corporate Law. 3rd Edition. Oxford: University Press, 281 p.

Lanskov D.P., Danilova S.A. (2019) Complex of electronic relations between registrars, issuers and shareholders. Aktsionernoye obschestvo: voprosy corporativnigo upravlenia, special issue, no 9, pp. 13-17 (in Russian) 
Lysenko K.V. (2019) The choice is everything! Aktsionernoye obshestvo: voprosy korporativnogo upravlenia, no 9. Available at: URL: https://aojournal.ru/journal/lib/ejournal/detail/ArticlelD/1711/vybor-reshaet-vse (accessed: 4.02.2021) (in Russian)

Magdalinskaya Yu.V. (2020) Peculiarities of legal regulation of electronic voting of shareholders (e-voting). Informationnoye pravo, no 1, pp. 4448 (in Russian)

Matrenina K.Yu. (2017) Formation of electronic voting at elections in the Russian Federation and the prospects for its development (constitutionallegal study). Candidate of Juridical Sciences Thesis. Tyumen, 224 p. (in Russian)

Medvedeva T.M., Azimova L.V. (2020) Electronic technologies in corporate relations. Khozyaistvo i pravo, no 9, pp. 65-79 (in Russian)

Murashov M.V., Papin E.N., Voziyan V.Yu. (2020) Electronic voting a new level. Aktcionernoye obschestvo: voprosy corporativnogo upravlenia, no 9. Available at: URL: https://ao-journal.ru/) (accessed: 10.04.2021) (in Russian)

Novoselova L., Medvedeva T. (2017) Blockchain for shareholders voting. Khozyaistvo i pravo, no 10, pp. 10-21 (in Russian)

Pavlushkin A.V., Postnikov A.E. (2009) Legal mechanism of remote electronic voting (analysis of a possible model). Zhurnal rossiyskogo prava, no 11, pp. 5-13 (in Russian)

Saccone F. (2010) E-Proxy reform, activism, and decline in retail shareholder voting. The Conference Board Director Notes no DN-021. Available at: https://ssrn.com/abstract $=1731362$ (accessed: 1.03 .2021 )

Sychev P.G. (2011) New legislative initiatives: protection of the corporate governance system or a gift to raiders? Bezopasnost biznesa, no 1, pp. 30-34 (in Russian)

Tsaplin A.Yu. (2016) Prospects for remote electronic voting in Russia. Izvestia Saratovskogo gosudarstvennogo universiteta. New Seria: Sociologia. Politologia, no 3, pp. 345-350 (in Russian)

Zakuskin A.A. (2019) Introduction of electronic technologies into the Russian electoral process. Vestnik Mariyskogo gosudarstvennogo universiteta. Seria Istoricheskie nauki. Yuridicheskie nauki, no 3, pp. 277281 (in Russian)

Zetzsche D. (2007) Virtual shareholder meetings and the European shareholder rights directive: challenges and opportunities. Available at: https://ssrn.com/abstract=996434 (accessed: 1.03.2021)

Zhiznenko O. (2020) How electronic voting of shareholders is developing in Russia and the world. Available at: URL: https://pro.rbc.ru/demo/ 5e2aa3819a794768c792e071 (accessed: 4.02. 2021) (in Russian) 